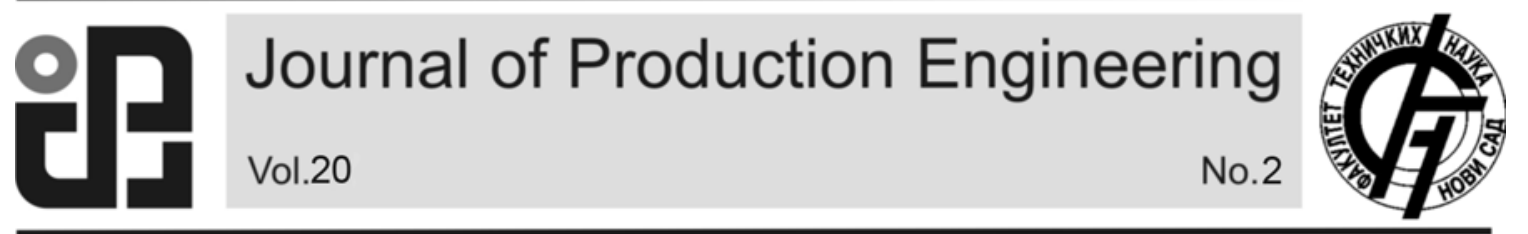

JPE (2017) Vol.20 (2)

Edibo, S., Ofuyekpone, O., Edoziuno, F.O., Adediran A.A.

Preliminary Note

\title{
MOULDING PROPERTIES OF RIVER NIGER SAND (IDAH DEPOSIT) BONDED WITH IYOLOKO CLAY AND CASSAVA STARCH
}

Received: 02 November 2017 / Accepted: 12 December 2017

\begin{abstract}
The foundry properties of river Niger sand (Idah deposit) bonded with Iyoloko clay and cassava starch were evaluated. Impurities and other foreign objects were removed by washing and sorting, sieve analysis of Idah sand deposit revealed a grain fineness number (GFN) of 40.03 which belongs to the group of grain fineness number that has wide application in sand casting. Above 95\% bulk of the sand was retained after the first few sieves, hence the sand was considered to have met the American Foundrymen's Society (AFS) standard specification for moulding sand. Energy Dispersive X-Ray Fluorescence Spectrometer was used to carry out the chemical analysis of the sand and clay samples. From the results obtained, the sand was of high silica content (95.93\%) while the clay was rich in silica and alumina contents $(65.40 \%$ and $20.30 \%$ respectively). It was further observed that the sand deposit also maintained its refractoriness at above $1000^{\circ} \mathrm{C}$. Moulding properties investigated are green compression strength, dry compression strength, green shear strength, dry shear strength, permeability and compactibility were determined using a motor driven universal sand strength machine and its accessories and electric permeability meter. The mechanical and physical properties of the aluminium alloy casting produced with the local sand compared favourably with typical mechanical properties for aluminium alloys. Therefore, foundry moulds produced from this sand deposit bonded with Iyoloko clay and cassava starch is suitable for casting aluminium alloys.
\end{abstract}

Key words: Binder, Permeability, dry compression strength, green compression strength, compactibility.

Osobine peska reke Niger za pravljenje kalupa (idah deposit) spojeni sa Iioloko glinom i kasava skrobom. Ocenjene su osobine peska reke Niger za livenje (deponije Idah) spojene sa Iioloko glinom i kasava skrobom. Nečistoće i ostali strani predmeti uklonjeni su pranjem i sortiranjem, sito analiza deponije peska Idah otkrila je broj zrna (GFN) od 40.03 koji spada u grupu čestice zrnatosti zrna koja ima široku primenu za livenje u pesku. Veća količina od 95\% peska zadržano je posle prvih nekoliko sita, pa se smatra da je pesak dostigao standardnu specifikaciju američkog livačkog društva (AFS) za oblikovanje peska. Energetski disperzivni rentgenski fluorescentni spektrometar korišćen je za izvođenje hemijske analize uzoraka peska i gline. Iz dobijenih rezultata, pesak je bio visokog sadržaja silicijuma (95,93\%), dok je glina bila bogata sadržajima silike $i$ glinice $(65,40 \% i$ $20,30 \%$ respektivno). Dalje je primećeno da depozit peska zadržava i svoju refraktornost na preko $1000^{\circ} \mathrm{C}$. Ispitane osobine livačkih karakteristika su zelena jačina kompresije, jaka kompresiona čvrstoća, jačina čvrstoće smicanja, čvrstoća na suvom smicanju, prepustljivost i kompaktibilnost korišćenjem univerzalne mašine za čvrsto širenje peska i njegovog pribora i merača električne propusnosti. Mehaničke i fizičke osobine livenja aluminijumske legure proizvedene sa lokalnim peskom u poređenju sa tipičnim mehaničkim svojstvima aluminijumskih legura. Zbog toga, livački kalupi proizvedeni iz ovog depozita od peska vezanog sa Iioloko glinom i kasava skrobom pogodan je za livenje aluminijumskih legura.

Ključne reči: Vezivo, permeabilnost, čvrstoća na suvom smicanju, jačina kompresije, kompatibilnost.

\section{INTRODUCTION}

Sand is the principal material in sand casting operation. Moulding sand ingredients consist essentially of silica sand, clay, water and other additives [1-3]. Sand is the base refractory material, while clay serves as suitable bonding agent for moulding mixtures. Water is added to develop strength and plasticity, hence, the moisture content is regulated between $4-6 \%$ [4]. Above 6\% causes decrease in permeability, while below $4 \%$ does not provide sufficient plasticity and bond strength to the mould [57]. Other addictive serve special purposes, ranging from bonding, improving high temperature plasticity and hot strength, producing anti-metal penetration properties and impart good surface finish to the casting $[1,8,9]$. Moulding sand can be classified into natural and synthetic moulding sands. Natural moulding sand are obtained directly from the source, particularly from the river or dug from the pit and used essentially as it is. It contains about $10-15 \%$ clay in contact with the silica sand. Natural moulding sand is not suitable for steel casting because $\mathrm{K}_{2} \mathrm{O}, \mathrm{Na}_{2} \mathrm{O}$, FeO present reduce its refractoriness, hence the need for composition of synthetic moulding sand from locally available raw materials [10-11]. One reason for the resort to use of synthetic moulding sand is attributed to its economy and ease of control. The sand is blended with clay, water and other required additives in the right proportion before use. It can be employed for ferrous casting moulds and others that require high refractoriness.

A variety of casting methods is available, the choice of methods depending on a numbers of factors, including size of casting required, surface finish and cost per component. Sand casting process involves low capital 
cost and cost of operation, possibility of large tonnage casting, near net shape casting, reusable characteristics of sand and surface finish achieved by proper sand control. It is this process flexibility that have resulted in the continuous use of sand casting method [12,5].

The quality of casting produced depends largely upon the properties of sand utilized. To ensure good casting, the sand must satisfy specifications as to refractoriness, bond strength, permeability, grain fineness, and moisture content $[10,8]$. Hence, this work explores the foundry properties of Niger sand (Idah deposit) bonded with Iyokolo clay and cassava starch.

\section{MATERIALS AND METHODS}

\subsection{Materials}

The materials used in this research includes silica sand from river Niger (Idah deposit), Iyoloko clay, cassava starch sediment and aluminum alloy from motorcycle hub. The equipment used include stack of standard sieves mounted on a sieve shaker, standard sand rammer, electric motor driven universal sand strength machine, electric permeability meter, laboratory core baking oven $\left(40{ }^{\circ} \mathrm{C}-240{ }^{\circ} \mathrm{C}\right)$, heat treatment furnace of $1100{ }^{\circ} \mathrm{C}$ capacity, energy dispersive X-ray fluorescence spectrometer, metallurgical bench microscope, electric Rockwell hardness testing machine and universal tensile strength testing machine.

\subsection{Methods}

Silica sand was collected from river bed some 320 $\mathrm{m}$ from river bank was washed thoroughly, sun dried and sorted ready for sieve analysis. Iyoloko clay dugged form Iyoloko stream bed in lumps was spread and dried in the sun. The sun dried clay was crushed and finely ground to pass through a sieve of 200-250 mesh size. Fresh tuber of cassava were selected, peeled and grate using a motorized grater. The grate paste on the screen was washed and as much starch as possible passed through the screen into a little water. The white milky water was channeled into a shallow container where sedimentation took place. Excess water was removed and the sediment (starch) was sun dried and reduced into powdered form, ready for use.

\subsubsection{Sieve Analysis}

$100 \mathrm{~g}$ of sand sample was weighed and passed successively through an arrangement of set of sieve mounted on a sieve shaker. Each sieve oversize retained on the sieves was collected. The sieves set were arranged in a descending order in a stack with the coarsest sieve on top and the finest at the bottom. The sample was turned into the uppermost sieve and the sieve shaker was allowed for a shaking time of $15 \mathrm{~min}$. The result of sieve analysis shown on Table 3 was used to compute the grain fineness number (GFN).

\subsubsection{Chemical Analysis of the Samples}

Energy dispersive $\mathrm{x}$-ray fluorescence spectrometer (ED-XRFS) was used for the chemical analysis of the aluminum alloy cast, the silica sand and the clay samples. In this process, high energy x-ray beam was allowed to pass through the samples, which caused the samples to generate $\mathrm{x}$-ray characteristics of the atoms in the sample. Elements present in the sample were identified from the energies of the characteristics radiation, while the concentration were evaluated from the intensity measurement of the radiation. The result of the ED-XRFS chemical analysis (Tables 1 \& 2) were reported in percentages for minor and major concentrations of element.

\subsubsection{Mixing Procedure}

The sand, clay, cassava starch and water were all mixed in a laboratory sand mixer. This was made possible by weighing the quantity of the sand, clay, starch, and measurement of a suitable liter(s) of water. The mixing proportions of the sample is shown in Table 1.

Weight of composed moulding mixture $=1000 \mathrm{~g}$

\begin{tabular}{lllll}
\hline Sample & Sand & Clay & Starch & Water \\
\hline Wt. $\%$ & 80 & 12 & 4 & 4 \\
\hline
\end{tabular}

Table 1. Samples mixing proportions

\subsubsection{Specimen Preparation}

AFS standard specimen of moulding sand was used with Ridsdale laboratory sand rammer. $170 \mathrm{~g}$ weight of moulding sand was compacted in the specimen tube by inserting the tube under the plunger and rammed with three drops of the sliding weight of the cam by turning the cam handle three revolutions. The specimens were then stripped from the tube by inverting over the stripping post and pushing the tube gently downward.

\subsubsection{Green Compression Strength (GCS) Test}

GCS test was carried out in a universal sand strength machine (USSM) the rammed standard specimen was carefully inserted in between the compression heads at the lower arm of the machine. The machine was put on and the magnetic rider gradually moves along the reading scale. The compression proceeds until fracture at the maximum strength of the specimen. The machine reverses and returns to zero automatically, while the magnetic rider remains in the position of the ultimate strength. The green compression strength is then read from the scale.

\subsubsection{Dry Compression Strength (DCS) Test}

Here, the AFS standard specimen was dried in a laboratory core baking oven for a period of $2 \mathrm{~h}$ at a temperature of $110{ }^{\circ} \mathrm{C}$ and then allowed to cool in ambient air. The test was carried out in the same manner as explained in GCS test. But in this case, the dried specimen was inserted into the compression heads place in the upper arm of the machine. This position increases the load applied by a factor of 5 . The dry compression strength is read from the scale marked "dry compression strength" at the point of specimen fracture and multiplied by 5 .

\subsubsection{Green Shear Strength (GSS) Test}

The green shear strength test is carried out in the same way as explained for dry compression strength, but the compression heads was replaced will shear 
heads.

The dry shear strength multiplied by the factor of 5 was recorded at the point where the specimen shears by reading the scale designated "dry shear strength".

\subsubsection{Permeability Test}

AFS standard specimen retained in the specimen table was mounted on the electric permeability meter which employs the orifice method for the rapid determination of moulding sand permeability. The equipment operates by passing air at constant pressure through the standard test specimen, and the drop in pressure is measured in a pressure gauge which is calibrated directly in permeability number.

\subsubsection{Compactibility Test}

The test was run by filling the AFS standard specimen tube with sand. The sand stuck level with the top of the tube and then the sand was rammed the standard 3 ramming blows by the rammer. The reduction in the height of sand from the top of the tube to the level of the rammed sand is read as the percentage compatibility, by dividing the decrease in height by the initial height.

\subsection{Refractoriness Test}

The test was carried out on $50 \mathrm{~g}$ of the River Niger sand (Idah deposit) the sample was place in a stainless steel cup and heated at about $14.3^{\circ} \mathrm{C} / \mathrm{min}$ in a heating furnace up to $1100{ }^{\circ} \mathrm{C}$ and held for $1.13 \mathrm{~h}$. The sand sample was then observed for fusion of the particles.

\subsection{Mechanical Analysis Of Aluminum Alloy Cast}

The mechanical properties considered include hardness test, tensile strength test and microstructural examination of the cast material.

\subsection{Metallography Examination}

Microscopic examination was carried out on a prepared cast sample to determine the grain size and the distribution of various phases present in the aluminum alloy cast as well as the inclusions.

The sample was view under a metallurgical bench microscopic with the following magnification of lenses.

Objective lens $=\mathrm{X} 10$

Viewing eye piece $=\mathrm{X} 10$

Camera eye piece $=\mathrm{X} 12.5$

Magnification, $\mathrm{M}$ = objective lens $\mathrm{X}$ viewing eye piece (during structural viewing)

$\mathrm{M}=10 \times 10=\mathrm{X} 100$

Magnification in photomicrograph (Plate 1)

$\mathrm{M}=10 \times 12.5=\mathrm{X} 125$

\section{RESULTS AND DISCUSSION}

\subsection{Results}

\subsubsection{Hardness Test of Cast Product}

The Rockwell hardness testing machine make use of a diamond penetration ' $\mathrm{c}$ ' scale for hard materials and hardened steel ball (as used in this work) for softer steels and non-ferrous metals. The diameter of the steel ball used is $1.78 \mathrm{~mm}$. The load applied is 998 RHB which is equivalent to $100 \mathrm{~kg}$ force. The Rockwell hardness machine used is electrically operated and has a scale for reading the hardness values with the sample rigidly held on the supporting head, the load was applied and hardness recorded as shown in Table 7.

\subsubsection{Tensile Strength Test}

The universal tensile strength testing machine was used. $0.2 \%$ proof stress was used to determine the tensile strength. During the experiment, the following data were used to calculate the tensile strength.

Initial gauge length $\left(G_{0}\right)=50 \mathrm{~mm}$

Final gauge length $\left(\mathrm{G}_{\mathrm{f}}\right)=50.9 \mathrm{~mm}$

Initial diameter $\left(\mathrm{D}_{\mathrm{o}}\right)=11.9 \mathrm{~mm}$

Final diameter $\left(\mathrm{D}_{\mathrm{f}}\right)=11.75 \mathrm{~mm}$

Proof load $\left(\mathrm{Y}_{\mathrm{L}}\right)=14658 \mathrm{~N}$

Maximum load $\left(\mathrm{M}_{\mathrm{L}}\right)=18094 \mathrm{~N}$

The following relations are used to calculate the results of various tensile strength properties

Proof stress $\left(\mathrm{P}_{\mathrm{s}}\right)=\frac{Y_{L}}{A_{O}}$,

Ultimate tensile strength UTS $=\frac{M L}{A_{O}}$

Percentage Elongation (\%E) $=\frac{G_{f}-G_{O}}{G_{O}} \times 100 \%$

reduction in cross-sectional Area $(\% \mathrm{RCSA})=\frac{A_{O}-A_{f}}{A_{O}}$

$\times 100$

$\mathrm{A}_{0}=\frac{\pi\left(D_{O}\right)^{2}}{4}, \mathrm{~A}_{0}=111.22 \mathrm{~mm}^{2}$
$\mathrm{~A}_{\mathrm{F}}=\frac{\pi\left(D_{r}\right)^{2}}{4}, \mathrm{~A}_{\mathrm{F}}=108.43 \mathrm{~mm}^{2}$
$\% \mathrm{E}=\frac{G_{f}-G_{O}}{G_{O}} \times 100=1.8 \%$
$\%$ R.C.S.A $=\frac{A_{O}-A_{f}}{A_{O}} \times 100=2.51$

(0.2\%) Proof Stress, $\mathrm{P}_{\mathrm{s}}=\frac{Y_{L}}{A_{O}}=131.79 \mathrm{~N} / \mathrm{mm}^{2}$

$\mathrm{UTS}=\frac{M L}{A_{O}}=162.69 \mathrm{~N} / \mathrm{mm}^{2}$

\subsection{Discussion}

The representative values of constituents compounds in Iyoloko clay and Idah sand are presented in Table 2, Table 3 shows the various trend in values of moulding properties of Idah silica sand while Tables 47 shows the sieve analysis against grain fineness number, composition of casting of cast Al alloy, result of tensile test of $\mathrm{Al}$ alloy cast with Idah silica sand and hardness test result of $\mathrm{Al}$ alloy cast with Idah silica sand respectively.

The results of chemical analysis (Table 2) showed that Idah sand deposit is high in silica $(95.93 \%)$ and have good foundry properties. The standard properties of silica sand for foundry use includes $95-96 \%$ minimum silica $\left(\mathrm{SiO}_{2}\right)$ content, $0.3 \%$ maximum $\mathrm{Fe}_{2} \mathrm{O}_{3}$ content, $0.2 \%$ maximum $\mathrm{CaO}$ content, $0.5 \%$ maximum $\mathrm{K}_{2} \mathrm{O}$ content $0.5 \%$ maximum $\mathrm{Na}_{2} \mathrm{O}$ content [11]. While the percentages of the various constituent of the silica sand obtained from the analysis indicate that the sand have met the silica content standard. 


\begin{tabular}{|c|c|c|}
\hline Compounds & Iyoloko Clay & Idah Sand \\
\hline $\mathrm{Al}_{2} \mathrm{O}_{3}$ & 20.30 & 1.58 \\
\hline $\mathrm{SiO}_{2}$ & 65.40 & 95.93 \\
\hline $\mathrm{K}_{2} \mathrm{O}$ & 1.05 & 0.83 \\
\hline $\mathrm{CaO}$ & 0.79 & 0.14 \\
\hline $\mathrm{TiO}_{2}$ & 3.17 & 0.07 \\
\hline $\mathrm{ZnO}$ & 0.02 & - \\
\hline $\mathrm{MnO}$ & 0.13 & - \\
\hline $\mathrm{Fe}_{2} \mathrm{O}_{3}$ & 6.03 & 0.5 \\
\hline $\mathrm{MgO} \mathrm{Fe}_{2} \mathrm{O}_{3}$ & 0.18 & - \\
\hline $\mathrm{Na}_{2} \mathrm{O}$ & 6.03 & 0.5 \\
\hline
\end{tabular}

Table 2. Chemical compositions of Idah silica sand and Iyoloko clay deposits

The $\% \mathrm{Fe}_{2} \mathrm{O}_{3}$ from the chemical analysis indicate that the sand has not met the $\mathrm{Fe}_{2} \mathrm{O}_{3}$ content standard. The $\% \mathrm{k}_{2} \mathrm{O}$ obtained from the analysis is 0.83 , thus this have not met the required standard for $\mathrm{k}_{2} \mathrm{O}$ content. The value of $\mathrm{Na}_{2} \mathrm{O}$ content in the sample is $0.15 \%$, thus the sand deposit has met the specified standard for $\mathrm{Na}_{2} \mathrm{O}$ content. The refractoriness of the sand was maintained even at above $1000{ }^{\circ} \mathrm{C}$ as there was no fusing observe and the sand particles were independent despite the presence of this fusion inducing oxides in the sand deposit. Therefore, this sand can be used to produce mould for casting of aluminum alloys and other nonferrous alloys.

\begin{tabular}{|c|c|c|}
\hline Properties & $\begin{array}{l}\text { Iyoloko clays } \\
\text { as binder }\end{array}$ & $\begin{array}{l}\text { Bentonite } \\
\text { as binder }\end{array}$ \\
\hline GCS $\left(\mathrm{kN} / \mathrm{m}^{2}\right)$ & 16.8 & 123.2 \\
\hline GSS $\left(\mathrm{kN} / \mathrm{m}^{2}\right)$ & $\begin{array}{l}\text { (sand too weak } \\
\text { for strength } \\
\text { determination) }\end{array}$ & 29.4 \\
\hline DCS $\left(\mathrm{kN} / \mathrm{m}^{2}\right)$ & 546 & 1974 \\
\hline DSS $\left(\mathrm{kN} / \mathrm{m}^{2}\right)$ & 266 & 252 \\
\hline Compatibility (\%) & $33 \%$ & $45 \%$ \\
\hline Permeability (NO) & 600 & 863 \\
\hline \multicolumn{3}{|c|}{$\begin{aligned} \text { Note: } \text { GCS } & =\text { Green compression strength } \\
\text { GSS } & =\text { Green shear strength } \\
\text { GCS } & =\text { Dry Compression Strength } \\
\text { DSS } & =\text { Dry Shear Strength }\end{aligned}$} \\
\hline
\end{tabular}

Table 3. Moulding properties of Idah silica sand.

Results of moulding properties obtained using Iyoloko clay and cassava starch as binders (Table 3) did not compare favourably with those obtained using bentonite as binder, except the dry shear strength (DSS) which is higher than that obtained using standard industrial binder (bentonite). It could be inferred that Iyoloko clay and cassava starch require other additives or increasing the clay content for improved moulding properties, such as the dry and green strength and the permeability.

$$
\begin{aligned}
& \text { GFN }=\frac{\text { Total product }}{\text { Total } \% \text { Sand retained }} \\
& \text { GFN }=\frac{3997.394}{99.86}=40.03
\end{aligned}
$$

The sieve analysis (Table 4) revealed that the sand has met the American Foundrymen's society (AFS) standard specification for moulding sand, since above $95 \%$ of the bulk sand was retained on the first few sieves. The grain fineness number is 40.03 and this grade of fineness have wide range of application in sand casting [11].

\begin{tabular}{lllll}
\hline S/N & $\begin{array}{l}\text { SIEVE } \\
\text { APERTURE } \\
(\boldsymbol{\mu m})\end{array}$ & $\begin{array}{l}\text { BSS } \\
\text { NO }\end{array}$ & $\begin{array}{l}\text { \% SAND PRODUCT } \\
\text { RETAINE } \\
\text { D (g) }\end{array}$ \\
\hline 1 & 1600 & - & 4.606 & - \\
2 & 1000 & 10 & 5.607 & 56.07 \\
3 & 710 & 20 & 12.17 & 243.4 \\
4 & 630 & 30 & 4.15 & 124.3 \\
5 & 400 & 40 & 55.8 & 2232 \\
6 & 315 & 50 & 9.26 & 463 \\
7 & 200 & 70 & 7.55 & 528.5 \\
8 & 160 & 100 & 0.48 & 48 \\
9 & 125 & 140 & 0.2 & 28 \\
PAN & - & 200 & 0.7 & 14 \\
TOTAL & & 99.86 & 3997.394 \\
\hline
\end{tabular}

Table 4. Sieve analysis and grain fineness number (GFN) of Idah silica sand

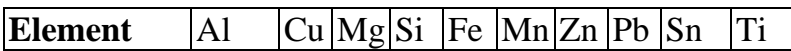
\begin{tabular}{|l|l|l|l|l|l|l|l|l|l|l|l|}
\hline Percentage & 90.59 & 1.5 & 0.6 & 5.5 & 0.6 & 0.5 & 0.1 & 0.1 & 0.05 & 0.21 \\
\hline
\end{tabular} Table 5. Chemical composition of cast aluminium alloy

\begin{tabular}{ll}
\hline 0.2 \% proof stress & 131.79 \\
U.T.S N/mm & \\
\% Elongation & 162.69 \\
\% Reduction in CSA & 1.8 \\
\hline
\end{tabular}

Table 6. Tensile value of Al alloy cast with Idah silica sand

\begin{tabular}{|l|c|c|r|c|}
\hline \multirow{2}{*}{ Property } & \multicolumn{3}{|c|}{ Hardness (RHB) } & \multirow{2}{*}{$\begin{array}{c}\text { Average } \\
\text { (RHB) }\end{array}$} \\
\hline \multirow{2}{*}{ Sample } & A & B & C & \multirow{2}{*}{48.1} \\
\cline { 2 - 4 } & 48.8 & 48 & 47.5 & \\
\hline
\end{tabular}

Table 7. Hardness value result of aluminium alloy cast with Idah silica sand

It is evident from the tensile strength results (Table 6) that $0.2 \%$ proof stress of the cast aluminium alloy is $131.79 \mathrm{~N} / \mathrm{mm}^{2}$ with a \% elongation of 1.8 . This result compared favorably with the standard, $0.2 \%$ proof stress of $130 \mathrm{~N} / \mathrm{mm}^{2}$ with corresponding percentage elongation of 1.3 [11].

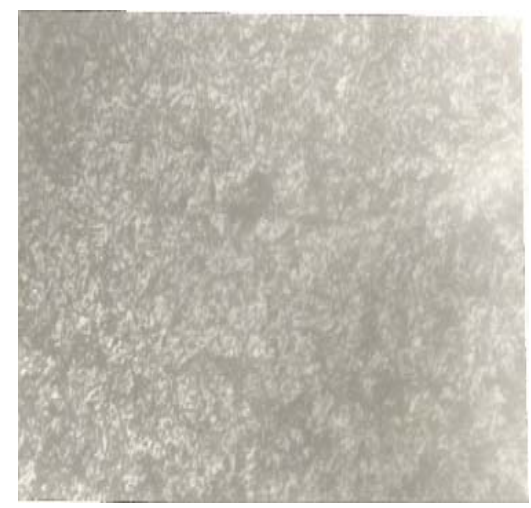

Plate 1. Photomicrograph of cast aluminium alloy using Idah silica sand (X100) 
The microstructural examination result (Plate 1) confirms the justification of the mechanical properties and the inference that harder materials have fine grain structure, while ductile materials have coarse grain structures. The photomicrograph is coarse, which is also a direct effect of the coarseness of the sand grains and permeability of the sand deposit.

\section{CONCLUSION}

From the results of this comparative evaluation, the following conclusions were made:

1. sand deposit met the minimum silica content requirement (95-96\%) for moulding sand. The sand also met the maximum $\mathrm{Na}_{2} \mathrm{O}$ content (0.5\%) requirement, but failed to meet the maximum content requirement for the other oxide contents. Nevertheless, the refractoriness of the sand was maintained at above $1000{ }^{\circ} \mathrm{C}$.

2. moulding properties of the sand bonded with Iyoloko clay and cassava starch is not suitable for adequate mould handling when compared with those obtained using bentonite.

3. microstructure of the cast aluminium alloy correspond with the permeability effect of the sand on the cast alloy.

4. the mechanical properties of the cast aluminium alloy from the sand deposit (proof stress of 131.79 $\mathrm{N} / \mathrm{mm}^{2}$ and $1.8 \%$ elongation) compared favourably with the typical mechanical properties for aluminium alloys.

\section{REFERENCES}

[1] American Foundrymen's Society, AFS. Moulding Methods and materials, AFS handbook, 1968.

[2] Edoziuno, F.O., Oyibo, A.O., Nwaeju, C.C. Preparation of Synthetic Moulding Sand Using Local Raw Materials. International Journal of Advanced Engineering and Technology, Vol.1(1), 2017, pp. 28-31.

[3] Edoziuno, F.O., Oyibo, A.O., and Odo, J.U. Effects of Particle Size, Clay and Moisture Contents on the Properties of Synthetic Moulding Sand. Proceedings of the 33rd Annual Conference of the Nigerian Metallurgical Society (NMS), Warri.
Nov. 01-04, 2017, pp.100-110.

[4] Edoziuno, F.O., Utu, O.G., and Nwaeju, C.C. Variation of Moisture Content with the Properties of Synthetic Moulding Sand Produced from River Niger Sand (Onitsha Deposit) and Ukpor Clay. International Journal of Research in Advanced Engineering and Technology, Vol.3(2), 2017, pp.102-106.

[5] Beeley, P.R. Foundry Technology, Butterworth Heinemann, 2001.

[6] Atanda, P.O., Olorunniwo, O. E., Alonge, K. and Oluwole, O. O. Comparison of Bentonite and Cassava on the Moulding Properties of Silica Sand. International Journal of Materials and chemistry, Vol. 2 , No.4 , 2012, pp. 132-136

[7] Edoziuno, F.O., Odo, J.U., and Nnuka, E.E. Effect of Ukpor Clay Content on the Properties of Synthetic Moulding Sand Produced from River Niger Sand. International Journal of Research in Advanced Engineering and Technology, Vol. 1(3), 2015, pp.12-16.

[8] Jain, P.L. Principles of Foundry Technology, $4^{\text {th }}$ ed, Tata McGraw-Hill Publishing Company Limited, Inddia, 2006

[9] Turkeli, A. Sand, Sand Additives, Sand Properties and Sand Reclamation, MSE-432 (Foundry Technology), Lecture Notes, 2008.

[10] Mclaws, I. J. Uses and Specifications of Silica Sand. Research council of Alberta, Report 7-41, 1971.

[11] Brown, J.R. Foseco Foudryman's handbook, $10^{\text {th }}$ ed, Butterworth Heinemann, Britain, 1994.

[12] American Foundrymen's Society, AFS: Foundry Sand Handbook; The America Foundrymen's Society. Des Plaines, Illinois, $7^{\text {th }}$ ed, 1963.

Authors: Edibo, S., Ofuyekpone, O., Edoziuno, F.O., Department of Metallurgical Engineering, Delta State Polytechnic, Ogwashi-Uku, Nigeria

Adediran, A.A., Department of Mechanical Engineering, Landmark University, Omu-Aran, Kwara State, Nigeria

e-mail: emmanueledibo78@gmail.com francisedoziuno@gmail.com dladesoji@yahoo.com 